University of Nebraska - Lincoln

DigitalCommons@University of Nebraska - Lincoln

Agronomy \& Horticulture - Faculty Publications

Agronomy and Horticulture Department

2016

\title{
Engaging Middle School Students through Locally Focused Environmental Science Project-Based Learning
}

\author{
Andrea D. Basche \\ University of Nebraska-Lincoln, abasche2@unl.edu \\ Vincent Genareo \\ Salisbury University \\ Adah Leshem \\ lowa State University \\ Amy Kissell \\ Brody Middle School \\ Judith Pauley \\ Brody Middle School
}

Follow this and additional works at: https://digitalcommons.unl.edu/agronomyfacpub

Part of the Agricultural Science Commons, Agriculture Commons, Agronomy and Crop Sciences Commons, Botany Commons, Horticulture Commons, Other Plant Sciences Commons, and the Plant Biology Commons

Basche, Andrea D.; Genareo, Vincent; Leshem, Adah; Kissell, Amy; and Pauley, Judith, "Engaging Middle School Students through Locally Focused Environmental Science Project-Based Learning" (2016). Agronomy \& Horticulture -- Faculty Publications. 1134. https://digitalcommons.unl.edu/agronomyfacpub/1134

This Article is brought to you for free and open access by the Agronomy and Horticulture Department at DigitalCommons@University of Nebraska - Lincoln. It has been accepted for inclusion in Agronomy \& Horticulture -Faculty Publications by an authorized administrator of DigitalCommons@University of Nebraska - Lincoln. 


\section{Engaging Middle School Students through Locally Focused Environmental Science Project-Based Learning

\author{
Andrea Basche,* Vincent Genareo, Adah Leshem, Amy Kissell, and Judith Pauley
}

\begin{abstract}
Increasing scientific literacy through education is one way to promote awareness of current environmental challenges, and can be enhanced through project-based learning (PBL), a pedagogical approach in which students explore authentic topics and demonstrate their learning publically. The National Science Foundation-funded GK-12 program at Iowa State University partnered doctoral-level graduate students (fellows) with middle and high school science teachers. This study analyzed results from one such middle school partnership in Iowa, where a PBL approach was implemented. Classroom practices focused on local environmental case studies of energy development, water pollution, soil science, climate change, plant biology, and ecology. Results from a student survey $(n=101)$, following a year with the PBL curricula, revealed significantly more positive attitudes and greater levels of engagement and confidence in scientific material relative to GK-12 peers $(n=329)$. Publicly submitted student letters to a government agency responsible for approving an oil pipeline project were also analyzed for scientific themes and levels of comprehension $(n=65)$. Overall, $60 \%$ of students demonstrated the ability to construct arguments by citing specific data and scientific evidence in the letters, and also incorporated topics covered in previous units ( $4-5$ themes addressed on average per letter). Results demonstrate that a PBL approach in a middle school science classroom is a method to stimulate attitudes, engagement, confidence, and comprehension in the study of environmental topics. Discussion follows about improving $\mathrm{K}-12$ science education to enhance public understanding and engagement around environmental policy issues.
\end{abstract}

\section{Core Ideas}

- A project-based learning approach involves public expression of meaningful topics.

- A middle school science class with a scientist-teacher partnership used this method.

- Students expressed more positive science attitudes and confidence than peers.

- Analysis of public letters on an energy project found complex argument construction.

- This approach may increase science engagement in science policy issues.

Published in Nat. Sci. Educ. 45 (2016)

doi: $10.4195 /$ nse2016.05.0012

Received 14 May 2016

Accepted 26 Oct. 2016

Available freely online through the author-supported open access option

Copyright (c) 2016 American Society of Agronomy

5585 Guilford Road, Madison, WI 53711 USA

This is an open access article distributed under the CC BY-NC-ND license (http://creativecommons.org/licenses/by-nc-nd/4.0/)

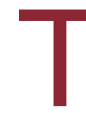
he scientific community recognizes that global environmental challenges of the 21 st century exceed those of any other time in modern history, given the influence of a period that ecologists have termed the anthropocene (Crutzen, 2002). Some of those global challenges involve the increase of water pollution, food insecurity for global citizens (Foley et al., 2011), exploitation of soil resources (Montgomery, 2007; Admundsen et al., 2015), unsustainable use of water resources (Jamarillo and Destouni, 2015), and climate change threatening the livelihood of future generations (Hansen et al., 2013). Other experts recognize that critical planetary boundaries, such as the integrity of the biosphere through preventing more biodiversity loss, may already have been surpassed (Steffen et al., 2015). Although scientific understanding and consensus is increasing on many of these issues, policy and public behavioral change happens at a slower place. Research, however, has demonstrated that climate change education highlighting local climate impacts is a critical approach for inspiring public support (Lee et al., 2015) and that presenting issues in a local frame has a positive impact on behavioral intentions (Wiest et al., 2015).

\section{GK-12 Background}

One promising program that addressed critical science, technology, engineering, and mathematics (STEM) issues in higher education and $\mathrm{K}-12$ classrooms was the Graduate STEM Fellows in K-12 in Education (GK-12) program. The GK-12 program originally launched in 1999, with universities and school districts across the nation partnering to pair graduate student scientists (fellows) with classroom teachers. These partnerships often followed one of two implementation models (Mitchell et al., 2003). The "exposition model" gave fellows opportunities to briefly present to $\mathrm{K}-12$ students and teachers, whereas the "classroom immersion model" paired fellows with $\mathrm{K}-12$ teachers throughout a school year to teach in the classroom. The majority of GK-12 programs, including the study at hand, used the classroom immersion model. Following a presidential call for more substantive STEM foci in $\mathrm{K}-12$ schools to address global environmental challenges (The White House, 2009), Iowa State University was

A. Basche, Union of Concerned Scientists, $1825 \mathrm{~K}$ Street NW Suite 800, Washington DC 20006; V. Genareo, Dep. of Teacher Education, Salisbury Univ., 1101 Camden Avenue, TE281G, Salisbury, MD 21801; A. Leshem, Center for Biorenewables Research, 2311 Biorenewables Building, Iowa State Univ., Ames, IA 50011; A. Kissell and J. Pauley, Brody Middle School, Des Moines Public Schools, 2501 Park Ave., Des Moines, IA 50321. *Corresponding author (abasche@ ucsusa.org).

Abbreviations: GK-12, Graduate STEM Fellows in K-12 Education Program; IB, International Baccalaureate; NGSS, Next Generation Science Standards; NSF, National Science Foundation; $\mathrm{PBL}$, projectbased learning; STEM, science, technology, engineering, and math. 
awarded National Science Foundation (NSF) GK-12 funding to focus on biorenewables and critical challenges in STEM.

Research on the GK-12 program showed encouraging benefits. Most research examined the impact of the programs on fellows and teachers. The experience of teaching science was shown to improve fellows' abilities in their own scientific research (Feldon et al., 2011), capacities to communicate science topics (Mitchell et al., 2003), and confidence in teaching and engaging students (Page et al., 2011). Teachers also benefitted from having a fellow in their classroom. The GK-12 program helped improve university and school partnerships and contribute to pedagogical and content knowledge of teachers (Mitchell et al., 2003; Stamp and O'Brien, 2005). Limited studies focusing on $\mathrm{K}-12$ students with a $\mathrm{GK}-12$ fellow have shown that the experience provided positive STEM models for $\mathrm{K}-12$ students and enriched students' content learning (Mitchell et al., 2003). Fellows often designed lessons that were more authentic to their fields and engaging to students than teachers may have otherwise (Moskal et al., 2007). Consequently, having a GK-12 fellow in the classroom helped students better understand the jobs of STEM practitioners, potentially increasing their interest in future STEM careers (Fralick et al., 2009).

\section{Project-Based Learning in Science}

The Next Generation Science Standards (NGSS, 2012) are beginning to be implemented in many states, with an aim to introduce and expand $\mathrm{K}-12$ curricula around some of the aforementioned 21st century environmental challenges and to increase scientific literacy for an educated society (NGSS, 2012). Further, the NGSS notes that a major difference in its conceptual framework is an explicit emphasis on science education as is it practiced in the real world (NGSS, 2013). This shift has the potential to be particularly impactful, as it is known that $\mathrm{K}-12$ students are generally eager to learn about and develop opinions on the broader planet (Jaus, 1982; Kinder et al., 2015). Although this offers great promise for students in states where NGSS are adopted, pedagogical strategies to introduce scientific concepts to students in a concrete manner remain important to develop a scientifically literate and politically engaged future electorate.

One strategy to engage $\mathrm{K}-12$ students with scientific concepts is Project-Based Learning (PBL), which is a pedagogical approach with roots in constructivism (Dewey, 1938; Krajcik et al., 1994). In PBL, students explore authentic, meaningful topics relevant to their lives and create artifacts that let them demonstrate their learning in a public way to serve as a record of their scientific engagement (Krajcik and Czerniak, 2014). Ill-defined issues, themes, or problems serve as the core inquiry of PBL. Teachers act as facilitators who help guide students to understand the issues and connect their learning to the content, whereas students collaborate with peers and adults to access information, investigate data, analyze the issues from multiple perspectives, and generate a product that attempts to investigate, scrutinize, and solve the problem (Harada et al., 2015).

Results of implementing PBL in science classrooms are promising; PBL has been shown to have a positive effect on students' science interests, critical thinking, science achievement, and collaborative skills (Neo and Neo, 2009). A recent randomized control trial in 42 6th grade classrooms found PBL-based curricula help students outperform those in traditional curriculum models on mastery of the NGSS standards (Harris et al., 2015). The authors saw the need for further studies that "focus on students applying disciplinary knowledge and making connections to crosscutting concepts as they engage in science and engineering practices, including in the context of project-based science" (Harris et al., 2015, p. 1381).

The purpose of this study was to evaluate the efficacy of a PBL approach used with middle school students to teach environmental science topics, through the unique curricula developed in a classroom with a GK-12 teacher-fellow partnership. To assess efficacy of the PBL approach, we analyzed survey results that addressed science attitudes, engagement, and confidence. We also analyzed a subset of publicly submitted letters regarding a proposed pipeline project in Iowa to evaluate recall of scientific themes and argument complexity.

\section{MATERIALS AND METHODS}

\section{GK-12 Context}

The present GK-12 program was a partnership between Iowa State University, an urban public school district, and the NSF (Award no. DGE-1007911). In this GK-12 program, a doctoral-level graduate student (fellow) was paired for the entirety of the school year with one particular science teacher as the "resident scientist" in the classroom. The fellows in this program were from a variety of disciplines, ranging from agronomy to electrical and computer engineering. To be considered for a fellow position, they completed an application essay and application form, submitted recommendation letters, and interviewed with GK-12 project leaders. Prior to the school year, GK-12 fellows received approximately 50 hours of professional development workshops in pedagogy, classroom technology, and communication strategies to students. These were followed by an intensive workshop for the fellows and their partner teachers.

\section{Context of the Science Curriculum}

Throughout the school year, the fellows worked with the classroom teachers to design lessons and pedagogical practices and teach one full day per school week for the duration of the school year. Within this school district's schedule, the fellows taught four different class sections ranging from 20 to 30 students per section. The middle school participating in this study followed the International Baccalaureate (IB) curriculum, which "aims to develop inquiring, knowledgeable and caring young people" who are "active, compassionate and lifelong learners" (IBO, 2014a, Mission Statement). The school's curriculum followed the district's science standards, which were aligned with state science standards and not based directly on the NGSS. Three fellows were placed in 7th grade classrooms in schools following the IB curriculum and one other GK-12 fellow taught in a 7th grade classroom at a school that did not follow the IB curriculum. One of these fellows implemented the PBL approach within the IB curriculum, and her projects are described next and are the focus of this research.

During the school year, multiple activities were implemented to engage students not only with the school district's curriculum but also with the various pedagogical strategies outlined by the IB guidelines, including global 
contexts and approaches to learning (Table 1). Global contexts were meant to help students address questions such as "why do people care about this topic" while providing students with a "common language for powerful contextual learning, identifying specific settings, events or circumstances that provide more concrete perspectives for teaching and learning" (IBO, 2014b, p. 58). The IB approaches to learning develop skills that help students "learn how to learn" and encompass both general and discipline-specific tools (IBO, 2014b, p. 20), such as critical-thinking and communication. Through the various approaches to learning and global context foci, topics related to environmental science and agronomy were introduced in the classroom; this included lessons on plant biology, soil science, climate science, and ecology (Table 1). Thus, the framework of the IB curriculum allowed for a strongly aligned integration of PBL approaches to science education in the classroom.

The middle school science students in this study also were instructed by a cohort of four teachers in content areas of science, math, literacy, and global studies. The IB curriculum created opportunities for the fellow and teacher partners to creatively collaborate with other teachers and stakeholders. As a result, several projects were put together, in partnership with the seventh grade literacy teacher, which gave students the opportunity to synthesize learning from prior lessons related to environmental science topics. Two of the collaborative projects are highlighted in the following sections and are meant to illustrate how activities were created that featured local topics of civic interest with a PBL approach.

\section{Environmental Science Project 1: Water Pollution in Iowa}

In fall 2014, the fellow and teacher partners created a unit on water issues. Lessons included a waterquality testing activity at a local lake, media analysis of international water challenges, and watershed model building to trace pollutant movement and landscape management as an intervention (Table 1). The culminating activity in this unit was a "round table", during which students researched and role-played one of several stakeholders involved in the public dialogues on water pollution in the state of Iowa. Water pollution is a newsworthy and critical issue in Iowa, as states bordering the Mississippi River were required to create plans for reducing water pollution given the hypoxic zone in the Gulf of Mexico (USEPA, 2013). Further, the Iowa Department of Natural Resources categorized more than 700 water bodies as impaired in the state (IDNR, 2015). Stakeholders included the local water utility, concerned citizens, farmers, government representatives, non-governmental agency representatives and scientists. Prior to the roundtables, a representative from each of the various stakeholder groups was invited to the school to speak to students and answer questions given their unique perspective on the topic of water pollution in Iowa. Through collaboration with the literacy teacher, all students constructed persuasive essays from their stakeholder's perspective on water pollution. A final assembly included speeches and questions from approximately 30 seventh grade students and was

Table 1. Overview of lessons developed by middle school science teacher and fellow. $\dagger$

\begin{tabular}{llll}
\hline $\begin{array}{c}\text { District curriculum unit } \\
\text { and topics }\end{array}$ & $\begin{array}{c}\text { International Baccalaureate } \\
\text { approach(es) to learning }\end{array}$ & $\begin{array}{c}\text { International Baccalaureate } \\
\text { global context(s) }\end{array}$ & Lessons related to environmental science \\
\hline $\begin{array}{l}\text { Characteristics of } \\
\text { living things }\end{array}$ & $\begin{array}{l}\text { Media and information literacy, } \\
\text { communication, collaboration, } \\
\text { critical thinking }\end{array}$ & $\begin{array}{l}\text { Water: globalization and } \\
\text { sustainability, fairness and } \\
\text { development }\end{array}$ & $\begin{array}{l}\text { Water quality testing at local lake, watershed } \\
\text { model making, interviews with local water stake- } \\
\text { holders, water pollution roundtable with USEPA } \\
\text { and Iowa DNR }\end{array}$
\end{tabular}

Scientific method: scientific and technical innovation
Chemistry

Science fair
Critical thinking, organization,

Communication, information literacy, creative thinking collaboration
Scientific and technical innovation, orientation in time and space

Scientific method: scientific and technical innovation
Plant activities: plant transpiration, fast plants, plant adaptations

Soil chemistry: soil cation exchange and charges

Introduction to environmental science and agronomy research

Experimental design, presentation practice

Carbon cycle game: dice game to move between sinks in Earth system

Soil biology: agar plate dilution of soil sample to observe bacteria and fungi

Soil profile: Symphony of the soil and soil profile "edible" models

Soil formation: Iowa soil regions activity and soil forming factors, celebrate Iowa soils planting prairie plants

Ecosystem ecology: food chains and energy transfer through ecosystems

Landscape ecology: PEWI model, land use, and environmental outcomes
Environmental science
Media and information literacy, Identities and relationships, communication, collaboration, critical thinking, creative thinking, organization globalization and sustainability, personal and cultural expression

† More information is available at Amelia Kissell's classroom page (http://mrsamykissell.wikispaces.com). 
attended by lead officials from the Iowa Department of Natural Resources and the Region 7 Environmental Protection Agency.

\section{Environmental Science Project 2: Crude Oil Pipeline Development}

In spring 2015, a multi-class activity was developed for students to explore the proposed Dakota Access Pipeline project. If approved, the pipeline would transport crude oil from North Dakota to Illinois and transect the state of Iowa. Students received a series of documents, which were created by the teacher and fellow. The documents highlighted the environmental impacts of oil development, potential negative consequences for water and soil quality, job creation data, energy security information, and oil transport safety facts. In assigned groups of three to four, students reviewed the materials and role-played the regulatory body tasked with approving or rejecting the permit for the pipeline. This project's culminating activity involved group presentations to discuss students' decisions and how the data they had available informed it. Because the topic was still ongoing in the state, the regulatory agency overseeing the pipeline permit was accepting public comment letters. Through partnership with the literacy teacher, students concurrently created letters to the agency and submitted them. In total, approximately 100 letters from these students were filed in the public record from the middle school. Finally, a former member of the regulatory board visited the classroom to discuss views of the ongoing project and to answer student questions related to their research.

\section{Student Demographic Information}

A total of 421 students taught by four GK-12 fellows were included in this study (see Table 2 for a full list of available demographics). The PBL group included 92 7th grade students from the four PBL-based science classes. All classes in the PBL group were taught by one teacher-fellow partnership. For those who provided racial/ ethnic demographic information, 7 students were African American, 50 were Caucasian, 6 were Hispanic, and the remaining ( $n=16)$ were Asian, American Indian, or biracial. Of the 90 students who provided gender identification, 43 were female and 47 were male.
The full comparison group included 329 7th grade students taught by the three other teacher-fellow partnerships.

Among those who provided demographic information, there were 44 African American students, 70 Caucasian, 70 Hispanic, and the remaining ( $n=93)$ were Asian, American Indian, or biracial. Of the 304 students who provided gender identification, 146 were female and 158 were male. Due to the school contexts, the comparison group had a higher rate of non-Caucasian students than the PBL group.

From the full comparison group, another comparison group (IB curriculum sub-group) was extracted for further analyses. This group included only students $(n=238)$ who were in IB curriculum schools (from two of the three other GK-12 fellows). Using available data from this group, 42 students were African American, 43 were Caucasian, 32 were Hispanic, and the remaining $(n=72)$ were Asian, American Indian, or biracial. The available data showed 102 female and 113 male students in the IB curriculum sub-group.

\section{Middle School Surveys}

Students received paper surveys at the end of the year (May). The 48 survey items were generally Likerttype rating responses related to students' interest and confidence in STEM topics, ratings of learning experiences, and engagement in science activities. The results of this study compared the mean scores of this PBL-based course (PBL group; $n=92$ ) to two other groups of students also a part of the GK-12 program: (1) The full cohort of 7th grade students ( $n=329$, "full comparison group" in Tables 2 and 3) and (2) The subset of the first group for students whose schools also followed the IB curriculum ( $n=238$, "IB curriculum sub-group" in Tables 2 and 3). An independent-samples $t$ test measured differences between the two groups on the items relevant to science attitudes, engagement, and confidence. Analyses were run at the $95 \%$ significance level.

\section{Pipeline Case Study Document Analysis}

A subsample of the letters ( $n=65$ ) submitted publicly to the government office overseeing the pipeline permit was analyzed. The goal of this analysis was to determine the depth of the students' understanding of scientific topics, to evaluate which themes most frequently occurred (given

Table 2. Available demographic characteristics of student participants.

\begin{tabular}{|c|c|c|c|c|}
\hline $\begin{array}{c}\text { Demographic } \\
\text { data }\end{array}$ & Total & $\begin{array}{l}\text { PBL } \\
\text { group }\end{array}$ & $\begin{array}{c}\text { Full comparison } \\
\text { group }\end{array}$ & $\begin{array}{l}\text { IB curriculum } \\
\text { sub-group } t\end{array}$ \\
\hline$n \neq$ & 421 & 92 & 329 & 238 \\
\hline \multicolumn{5}{|l|}{ Gender } \\
\hline Female & 189 & 43 & 146 & 102 \\
\hline Male & 205 & 47 & 158 & 113 \\
\hline
\end{tabular}

$\begin{array}{lrr}\text { Ethnicity } & & \\ \text { African American } & 51 & 7 \\ \text { Asian } & 32 & 50 \\ \text { Caucasian } & 120 & \\ \text { Hispanic } & 76 & 11 \\ \text { Biracial } & 70 & 5 \\ \text { Native American } & 10 & \end{array}$

$\begin{array}{rrr}7 & 44 & 42 \\ 3 & 29 & 29 \\ 0 & 70 & 43 \\ 6 & 70 & 32 \\ 1 & 59 & 39 \\ 5 & 5 & 4\end{array}$

+ From the full comparison group of 7th grade students, 238 were students in schools with the IB curriculum (labeled IB curriculum sub-group). Because their data are a subset of the full comparison data, they are not added in the total column.

₹ Some student demographic data were missing from surveys, so the total $n$ does not match the total number of available demographic sub-data as reported. 
that many of the topics in the documents were those that were previously covered in the science curriculum), and to evaluate different indicators of argument complexity. To determine how students made sense of complex scientific issues, two members of the research team performed a document analysis of the student letters. Ten of the letters $(15.4 \%)$ were independently open-coded and codes that emerged were discussed. Following a comparison and discussion of the independent analyses, a coding rubric for subsequent letter analysis was developed. Ten more letters (15.4\%) were openly coded to compare once again. Although the coding was very similar, with only a few minor differences, the rubric was modified for clarity and content to ensure reliable coding as the researchers independently coded the remaining sample. Each researcher then coded half of the remaining letters ( $n=45)$ using the developed rubric. The final coding rubric analyzed students' depth of understanding through argument themes (number of occurrences) and counter arguments presented, inclusion of data, and citation of parallel incidents. We define

Table 3. Statistics of PBL and comparison groups, full group, and IB curriculum.

\begin{tabular}{|c|c|c|c|c|c|c|}
\hline Survey items & $n$ & Mean & SD & $M$ Diff & $t$ & $p$ \\
\hline \multicolumn{7}{|l|}{ Science attitudes } \\
\hline \multicolumn{7}{|l|}{ I enjoy learning the material in this class } \\
\hline PBL course & 93 & 4.26 & 0.82 & & & \\
\hline Full comparison group ${ }^{\dagger}$ & 324 & 3.66 & 1.09 & 0.60 & 3.99 & 0.000 \\
\hline IB curriculum sub-group $\neq$ & 235 & 3.59 & 1.15 & 0.67 & 4.28 & 0.000 \\
\hline \multicolumn{7}{|l|}{ I like science } \\
\hline PBL course & 91 & 4.21 & 0.75 & & & \\
\hline Full comparison group & 317 & 3.54 & 1.21 & 0.67 & 6.45 & 0.000 \\
\hline IB curriculum sub-group & 230 & 3.49 & 1.25 & 0.72 & 6.33 & 0.000 \\
\hline \multicolumn{7}{|l|}{ Science is fun } \\
\hline PBL course & 88 & 4.11 & 0.82 & & & \\
\hline Full comparison group & 321 & 3.56 & 1.19 & 0.55 & 5.05 & 0.000 \\
\hline IB curriculum sub-group & 233 & 3.52 & 1.20 & 0.59 & 5.08 & 0.000 \\
\hline \multicolumn{7}{|l|}{ Science engagement } \\
\hline \multicolumn{7}{|c|}{ Teacher uses a variety of classroom activities and resources } \\
\hline PBL course & 92 & 4.46 & 0.70 & & & \\
\hline Full comparison group & 320 & 4.00 & 1.00 & 0.46 & 4.92 & 0.000 \\
\hline IB curriculum sub-group & 233 & 4.01 & 0.99 & 0.45 & 4.53 & 0.000 \\
\hline \multicolumn{7}{|l|}{ My teacher encourages us to ask questions } \\
\hline PBL course & 91 & 4.37 & 0.77 & & & \\
\hline Full comparison group & 319 & 3.97 & 1.07 & 0.40 & 4.06 & 0.000 \\
\hline IB curriculum sub-group & 231 & 3.90 & 1.08 & 0.47 & 4.36 & 0.000 \\
\hline \multicolumn{7}{|l|}{ I like the teacher to give me the answers } \\
\hline PBL course & 92 & 2.43 & 1.12 & & & \\
\hline Full comparison group & 321 & 3.37 & 1.32 & -0.94 & 6.77 & 0.000 \\
\hline IB curriculum sub-group & 233 & 3.43 & 1.22 & -1.00 & 6.81 & 0.000 \\
\hline
\end{tabular}

Science confidence

I am confident that science can help solve world problems.

$\mathrm{PBL}$ course

Full comparison group

91

324

IB curriculum sub-group

I will be successful if I pursue a career in science

PBL course

Full comparison group

IB curriculum sub-group

Science confidence§

PBL course

Full comparison group

IB curriculum sub-group

Earth science confidence§

PBL course

Full comparison group

IB curriculum sub-group

$\begin{array}{lllll}4.18 & 0.80 & & & \\ 3.78 & 0.93 & 0.40 & 3.69 & 0.000 \\ 3.88 & 0.89 & 0.30 & 2.80 & 0.005 \\ & & & & \\ 3.46 & 1.12 & & & \\ 2.95 & 1.20 & 0.51 & 3.56 & 0.000 \\ 2.99 & 1.18 & 0.47 & 3.22 & 0.001 \\ & & & & \\ 3.20 & 0.72 & & & \\ 2.77 & 0.88 & 0.43 & 4.85 & 0.000 \\ 2.73 & 0.88 & 0.47 & 5.06 & 0.000 \\ & & & & \\ 2.70 & 0.82 & & & \\ 2.34 & 1.01 & 0.44 & 3.51 & 0.001 \\ 2.35 & 0.99 & 0.35 & 3.24 & 0.001\end{array}$

† The full comparison group is the full set of Grade 7 students in the GK-12 program compared with the PBL course students.

\# The IB curriculum sub-group is only students from the full comparison group who were involved in schools with a similar IB curriculum (2 schools, 2 fellow-teacher partners) and are compared with the PBL course students.

$\S$ These items were rated on a 4-point scale. The remaining items were 5-point scales. 
parallel incidences as those in which a student is able to cite a similar incident in their argument (e.g., if a student argues that oil spills are a potential hazard, they cite a real example of when an oil spill occurred). Finally, a Pearson Chi-Square Test for association examined whether there were significant differences between students' stance (accept/reject pipeline) and how they constructed their arguments (addressed opposing viewpoints, cited facts or data, and cited parallel incidences).

\section{RESULTS}

The results of the study are presented below. First, survey analysis results are reported, which compare the students in the PBL classrooms (PBL group) with those in other 7th grade GK-12 classrooms (full comparison group), and a subset of those students who also follow the IB curriculum (IB curriculum sub-group). Next, results of the analysis of students' letters are shared.

\section{Survey Analysis Results}

Analyses compared the PBL group with the full comparison group and IB curriculum sub-group on a number of items related to science attitudes, engagement, and confidence. About 90 students in the PBL group responded to each survey item and approximately 320 students in the full comparison group did the same. The PBL group was found to have significantly greater levels of attitudes, engagement, and confidence in science relative to the full comparison group and the IB curriculum sub-group (see Table 3 for means and significance levels of the findings).

\section{Science Attitudes}

Findings indicated the PBL group's attitudes toward science were significantly more positive than the full comparison group. Significant differences came in response to the 5-point scale items of science enjoyment. The PBL group significantly enjoyed learning the material in their science class more ( $m$ difference $=0.60$ ) and generally liked science more ( $m$ difference $=0.67$ ). (Note that when parenthetical mean differences are presented as positive, the PBL group mean was greater.) The PBL group also thought that science was significantly more fun ( $m$ difference $=0.55$ ). When analyses compared the PBL group to only the 7th grade students with an IB curriculum (IB curriculum sub-group), the difference in attitude between the PBL group and the IB curriculum sub-group was even greater (since the means of the latter group were lower than those of the full comparison group).

\section{Science Engagement}

Next, results showed that students in the PBL group believed their science engagement was significantly higher than those in the full comparison group. The PBL group rated significantly higher that their teacher used a variety of classroom activities and resources ( $m$ difference $=$ 0.46 ) and that their teacher encouraged them to answer questions ( $m$ difference $=0.40$ ). This indicates that the PBL group felt their fellow provided more learning opportunities and allowed them to engage more in scientific inquiry. Further, the PBL group answered the item "I like when the teacher gives me the answers" significantly lower than their 7 th grade peers ( $m$ difference $=-0.94$ ). This suggests that the PBL group was more eager to answer questions on their own and to think independently, and did not want to receive answers directly from the teacher as much as those in the full comparison group. When comparing engagement of the PBL group to the IB curriculum sub-group, the PBL group was still significantly greater. Notable is that the PBL group was significantly less likely than the IB curriculum subgroup to want their teachers to give them the answers ( $m$ difference $=-1.00$ ).

\section{Science Confidence}

Relative to the full comparison group, the PBL students expressed significantly greater confidence in science as a field and confidence in their abilities to do science. First, students in the PBL group felt more confident that science can help solve world problems ( $m$ difference $=0.40$ ). They were also more apt to feel successful if they pursued a career in science ( $m$ difference $=0.51$ ). Additionally, on 4-point scale items, the PBL group felt more confident in their own abilities in general science and earth science ( $m$ difference $=0.43,0.44$, respectively). When comparing confidence of the PBL group to the IB curriculum sub-group, the means of the PBL group remained significantly greater on all items.

\section{Analysis of Public Letters Filed Related to the Pipeline Project}

Sixty-five of the letters filed publicly with the pipeline regulatory agency were coded for relevant themes and the presence of data supporting students' arguments. Seventyeight percent ( $n=51$ ) of these letters suggested that the agency reject the pipeline permit, while the remaining $22 \%(n=14)$ suggested that it be approved. Among the $78 \%$ of student letters suggesting that the pipeline project be rejected, students explicitly cited an average of 4.8 justifications for the decision. The most commonly cited arguments against the approval of the pipeline related to environmental impacts. The letters frequently discussed oil spills (92.2\% of these letters), impacts to crop production potential $(72.5 \%)$, water pollution $(60.8 \%)$, wildlife safety $(56.9 \%)$, soil impacts $(31.4 \%)$, and climate change $(19.6 \%)$. Concerns related to eminent domain use (37\%) and were also included in the letters. See Table 4 for the full list of themes by student stance (approve/reject), including examples of student writing. Of the 51 student letters who rejected the pipeline, 24 were able to cite a parallel incident as an example; 33 cited facts or data, and 15 addressed the opposing viewpoint (e.g., "I know some people think it should be rejected, but...").

Among the $22 \%$ of student letters suggesting that the pipeline project be approved, students cited an average of 4.1 justifications. Most of the arguments in support of the pipeline related to economics. The most frequently cited themes included job creation $(92.9 \%)$, economic benefit $(78.6 \%)$, farmer compensation plans $(71.4 \%)$, safer transportation (57.1\%), and energy independence $(21.4 \%)$. Of the 14 student letters who approved the pipeline, none were able to cite a parallel incident as an example; six $(42.8 \%)$ cited facts or data, and eight (57.1\%) addressed the opposing viewpoint.

We then analyzed if students constructed their arguments significantly differently according to the number of occurrences of ideas within their paper. Overall, about $60 \%(n=39)$ of the letters cited specific data from the documents provided to students in class. About 37\% $(n=$ 24 , all from the pipeline rejecting letters) cited parallel 


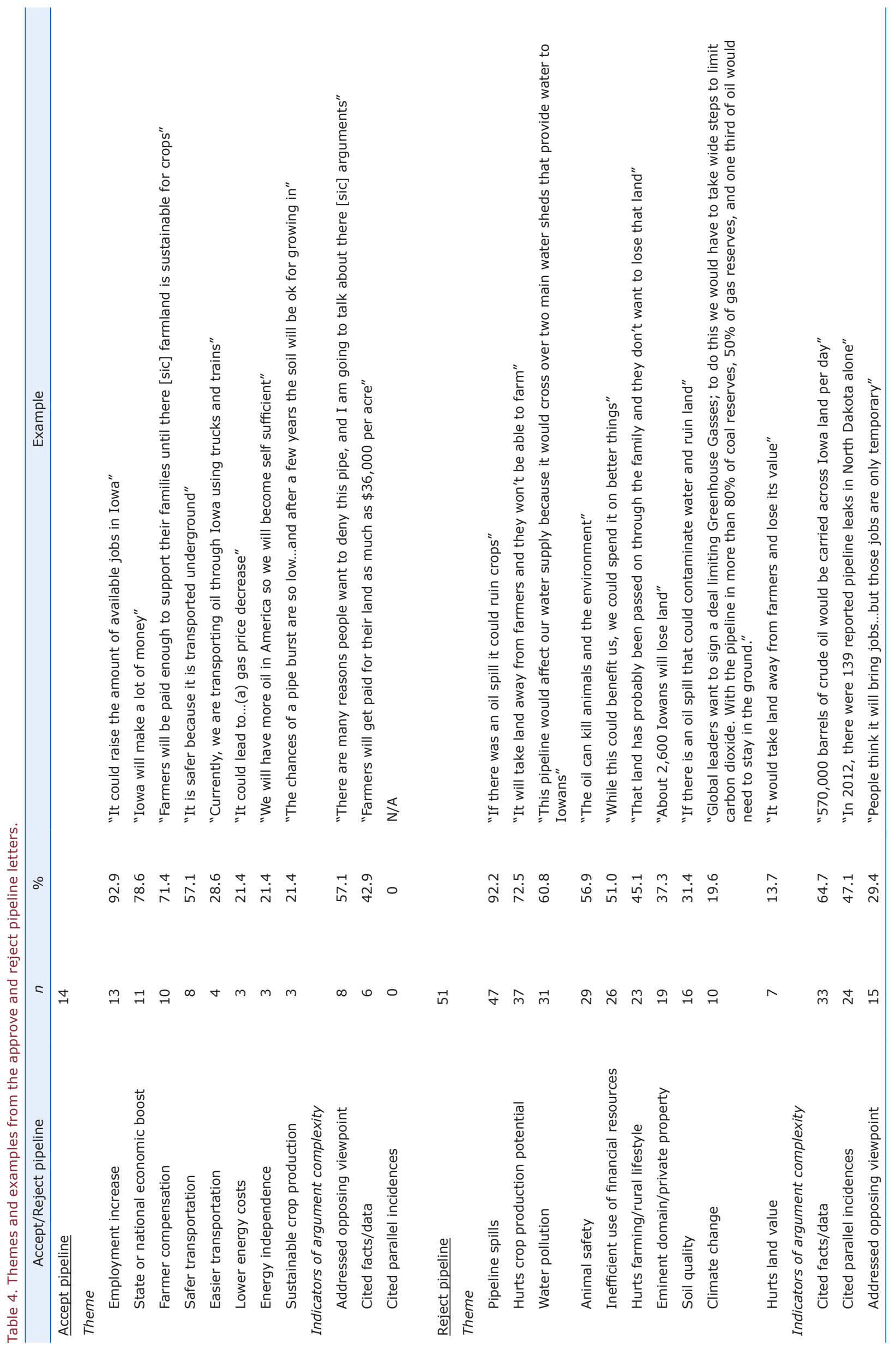


incidents related to similar pipeline failures, and about 35\% ( $n=23$ ) addressed the opposing viewpoints related to acceptance or rejection of the project. A Pearson Chi-Square Test revealed no significant differences between the accept and reject groups with regard to the number of opposing viewpoints they cited $(x[1]=3.70, p=0.055)$ or the number of cited facts or data they used in their arguments $(x[1]=2.19, p=0.139)$. There was a significant difference found in the number of parallel incidences cited in the papers between the two groups $(x[1]=7.39, p=0.000)$ because the students who took the stance to accept the pipeline did not cite any parallel incidences in their arguments; 14 students ( $27.5 \%$ of them) who argued to reject the pipeline did. Generally, students constructed their arguments in a statistically similar way, with one major difference: those who wanted the pipeline rejected were significantly more likely to formulate an argument that pulled in a real example supporting their claim.

\section{DISCUSSION}

The classroom analyzed in this research utilized a PBL approach (Table 1), and employed a hybrid of activities encompassing aspects of public engagement (i.e., public letters on oil pipeline), outdoor activities (e.g., native grasses planting, water quality testing at local lake), experimental design and data collection (e.g., science fair preparation and experiments), as well as computerbased learning modules (e.g., PEWI platform; Chennault et al., 2016). The results of this study demonstrate that the PBL approach stimulated middle school students' attitudes about, confidence in, and engagement with local environmental science issues.

It was promising that the PBL group was significantly less likely to want answers given to them directly by their teacher, indicating the PBL process of self-directed inquiry might have allowed them to value independent learning. It should be noted that all of the students in this survey participated in GK-12 teacher-fellow partnerships and, thus, were already involved in a unique program designed to increase engagement with science. They were likely receiving inquiry-based science instruction that was well planned and executed by a fellow with the assistance of a licensed teacher. However, these greater differences from the PBL group suggests that the PBL approach was successful at increasing student interest and engagement in scientific topics, even beyond the GK-12 programming. Not only did the PBL students enjoy the course and subject more, but they also appeared to become more independent and confident learners.

Findings from the student letter analysis showed that the majority of students $(60 \%)$ cited evidence in their letter arguments, reflecting their ability to utilize scientific evidence in construction of a complex, persuasive argument. The NGSS (2012) require students to cite evidence supporting their explanations, such as the Earth and Human Activity Standard MS-LS2-4: "Construct an argument supported by empirical evidence that changes to physical or biological components of an ecosystem affect populations." The National Science Teachers Association (NSTA, 2004) also recommended that teachers help students "learn how to draw conclusions and think critically and logically to create explanations based on their evidence [and] communicate and defend their results to peers and others." Students in this study appeared to do this, regardless of the stance (approve/reject) they chose, although those who wanted the pipeline rejected were more able to cite real examples to support their arguments.

In these student letters, a strong percentage of students cited opposing viewpoints in their letters, suggesting that many saw the relationship between the interconnected economic, social, and environmental issues surrounding the pipeline project. Although documents provided to students included information on soil quality, fossil fuel energy use, and climate change were discussed in several class lessons previous to the pipeline activity, a smaller percentage of students associated these topics with their persuasive arguments. A greater percentage of students chose to highlight impacts related to water pollution and crop production, topics also addressed previously in science class.

The importance of climate change and soil science as global 21st century challenges necessitate further discussion on integrating these topics into $\mathrm{K}-12$ education, and elements of a PBL approach might offer insight into how this might be accomplished. Through analysis of surveys from science teachers grades 5 to 12 on their challenges with climate change curriculum, White et al. (2014) proposed that more tailored climate change resources be developed that are region- and topic-specific to increase 7th to 12th grade students' exposure to climate change. Further, although there is a recent resurgence in soil as a topic of interest in science classrooms (United Nations Food and Agriculture Organization, 2015), it may still be relatively new to students in this setting. Given the global importance of soil management and conservation in the 21st century (Admundsen et al., 2015) and to stimulate declining and aging workforce in the field (Collins, 2008), other practitioners have developed specific soil science education interventions.

Similar to our classroom, Moebius-Clune et al. (2011) found that a soil science curriculum at the high school level implemented with similar attributes to a PBL-approach, emphasizing data collection and the scientific research process, significantly increased content knowledge and student excitement for soils topics. Soil science curricula at the undergraduate level that involve attributes of a PBL approach including experimental design, data collection, and local framing have also been shown to stimulate student confidence and problem-solving abilities (Krzic et al., 2015; Strivelli et al., 2011). Integrating topics such as soil science and climate change successfully into classrooms may be more effective when curricula are specifically tailored to student interests and needs, as was found to be successful in the PBL approach presented in this research study.

Education practitioners have similarly found that the use of such innovative classroom interventions lead to changes in attitudes among $\mathrm{K}-12$ students. For example, Klisch et al. (2012) found that an innovative online science game for 6th through 8th grade students significantly increased knowledge gained and led to a shift in attitude on toxic chemicals. Kinder et al. (2015) reported heightened senses of stewardship in 4th graders following completion of an outdoor watershed course. A survey that included $580 \mathrm{~K}-12$ students found that outdoor activities in natural environments, when integrated into the classroom, also increased students' inclinations toward stewardship and led to a desire to improve household environmental practices (Ballantyne and Packer, 2002). Further, an analysis of interviews with youth education practitioners across the 
United States concluded that action-based environmental education (a participatory educational approach that aligns with $\mathrm{PBL}$ ) is a preliminary step in a feedback loop that includes positive environmental and social change, as well as long-term democratic participation (Schusler et al., 2009). Overall, this study provides support for the efficacy of a PBL approach; a pedagogical strategy that integrates local environmental issues may not only increase students' science attitudes, engagement, and confidence, but may allow students to construct meaningful arguments, synthesized from classroom learning, as they engage in political discourse.

\section{CONCLUSION}

In this study, a GK-12 fellow employed PBL in a classroom to engage middle school students with critical issues in science. Although the GK-12 program has been phased out, the findings gleaned from the PBL approach to environmental education are still relevant and applicable to other middle school classrooms working to implement the NGSS. Results found positive effects on students' science attitudes, engagement, and confidence, even compared with other 7th grade students in both the GK-12 program and other IB curriculum schools. The unique PBL approach, developed by licensed teachers and the fellow, presented an opportunity for students to explore relevant local environmental science themes and meaningfully express their evidence-informed perspectives. The PBL approach demonstrated efficacy in this middle school classroom that may serve as a model to stimulate science engagement ultimately with an opportunity to foster a more scientifically literate public on important environmental issues.

\section{ACKNOWLEDGMENTS}

This research was a part of the National Science Foundation funded GK-12 program award no. DGE-0947929. The authors would like to thank Timm Pilcher and Megan Vanderflute of Brody Middle School for their feedback and earlier versions of this work. The authors would also like to thank Mari Kemis of the Research Institute for Studies in Education at Iowa State University for her guidance in preparation of this manuscript.

\section{REFERENCES}

Admundsen, R., A.A. Berhe, J.W. Hopmans, C. Olson, A.E. Sztein, and D.L. Sparks. 2015. Soil and human security in the 21st century. Science 348:1261071-1-1261071-6. doi:10.1126/ science. 1261071

Ballantyne, R., and J. Packer. 2002. Nature-based excursions: School students perceptions of learning in natural environments. Int. Res. Geogr. Environ. Educ. 11:218-236. doi: $10.1080 / 10382040208667488$

Chennault, C.M., L.A. Schulte, and J.C. Tyndall. 2016. People in Ecosystems Watershed Integration: A web-based learning tool for evaluating ecosystem service tradeoffs from watersheds. J. Soil Water Conserv. 71:31A-36A. doi:10.2489/jswc.71.2.31A

Collins, M.E. 2008. Where have all the soil science students gone? J. Nat. Resour. Life Sci. Educ. 37:117-124. doi:10.2134/ jnrlse2008.371117x

Crutzen, P. 2002. Geology of mankind. Nature 415:23. doi: $10.1038 / 415023 a$

Dewey, J. 1938. The theory of enquiry. Holt, Rinehart, and Wiston, New York.
Feldon, D.F., J. Peugh, B.E. Timmerman, M.A. Maher, M. Hurst, D. Strickland, J.A. Gilmore, and C. Stiegelmeyer. 2011. Graduate students' teaching experiences improve their methodological research skills. Science 333:1037-1039. doi:10.1126/ science. 1204109

Foley, J.A., N. Ramankutty, K.A. Brauman, E.S. Cassidy, J.S. Gerber, M. Johnston, N.D. Mueller, C. O'Connell, D.K. Ray, P.C. West, C. Balzer, E.M. Bennett, S.R. Carpenter, J. Hill, C. Monfreda, S. Polasky, J. Rockstrom, J. Sheehan, S. Siebert, D. Tillman, and D.P.M. Zacs. 2011. Solutions for a cultivated planet. Nature 478:337-342. doi:10.1038/nature 10452

Fralick, B., J. Kearn, S. Thompson, and J. Lyons. 2009. How middle schoolers draw engineers and scientists. J. Sci. Educ. Technol. 18:60-73. doi:10.1007/s10956-008-9133-3

Hansen, J., P. Kharecha, M. Sato, V. Masson-Delmotte, F. Ackerman, D.J. Beerling, P.J. Hearty, O. Hoegh-Guldberg, S. Hsu, C. Parmesan, J. Rockstrom, E.J. Rohling, J. Sachs, P. Smith, K. Steffen, L.V. Susteren, K. von Schuckmann, and J.C. Zachos. 2013. Assessing "Dangerous Climate Change": Required reduction of carbon emissions to protect young people, future generations and nature. PLoS One 8(12):e81648. doi:10.1371/ journal.pone.0081648

Harada, V.H., C. Kirio, and S. Yamamoto. 2015. Project-based learning: Rigor and relevance in high schools. In: J. Reman and G.K. Dickinson, editors, School Library Management, 7th edition. Santa Barbara, CA. p. 157-160.

Harris, C.J., W.R. Penuel, C.M. D'Angelo, A.H. DeBarger, L.P. Gallagher, C.A. Kennedy, B.H. Cheng, and J.S. Krajcik. 2015. Impact of project-based curriculum materials on student learning in science: Results of a randomized controlled trial. J. Res. Sci. Teach. 52:1362-1385. doi:10.1002/tea.21263

International Baccalaureate Organization (IBO). 2014a. Middle Years Programme Sciences guide: For use from September 2014/ January 2015. International Baccalaureate Organization (UK) Ltd, Wales, UK.

International Baccalaureate Organization (IBO). 2014b. Middle Years Programme from principles to practice: For use from September 2014/January 2015. International Baccalaureate Organization (UK) Ltd, Wales, UK.

Iowa Department of Natural Resources (IDNR). 2015. Understanding Iowa's impaired waters. http://www.iowadnr. gov/Environmental-Protection/Water-Quality/WatershedImprovement/Impaired-Waters (accessed 19 Dec. 2015).

Jamarillo, F., and G. Destouni. 2015. Local flow regulation and irrigation raise global human water consumption and footprint. Science 350:1248-1251. doi:10.1126/science.aad1010

Jaus, H.H. 1982. The effect of environmental education instruction on children's attitudes toward the environment. Sci. Educ. 66:689-692. doi:10.1002/sce.3730660504

Kinder, T., N.O. Mesner, M. Larese-Casanova, K.H. Lott, A. Cachelin, and K. LaLonde. 2015. Changes in knowledge and attitude from a short-term aquatic education program. Nat. Sci. Educ. 44:1825. doi: $10.4195 /$ nse2014.10.0024

Klisch, Y., L.M. Miller, S. Wang, and J. Epstein. 2012. The impact of a science education game on students' learning and perception of inhalants as body pollutants. J. Sci. Educ. Technol. 21:295-303. doi:10.1007/s10956-011-9319-y

Krajcik, J.S., P.C. Blumenfeld, R.W. Marx, and E. Soloway. 1994. A collaborative model for helping middle grade science teachers learn project-based instruction. Elem. Sch. J. 94:483-497. doi: $10.1086 / 461779$

Krajcik, J.S., and C.M. Czerniak. 2014. Teaching science in elementary and middle school: A project-based approach. Routledge, New York.

Krzic, M., A.A. Bomke, M. Sylvestre, and S.J. Brown. 2015. Teaching sustainable soil management: A framework for using problem-based learning. Nat. Sci. Edu. 44:43-50. doi:10.4195/ nse2014.07.0015

Lee, T.M., E.M. Markowitz, P.D. Howe, C. Ko, and A.A. Leiserowitz. 2015. Predictors of public climate change awareness and risk perception around the world. Nat. Clim. Change 5:1014-1020. doi: $10.1038 /$ nclimate 2728 
Mitchell, J., R. Levine, R. Gonzalez, C. Bitter, N. Webb, and P. White. 2003. Evaluation of the National Science Foundation Graduate Teaching Fellows in K-12 Education (GK-12) Program. Paper presented at The Annual Meeting of the American Educational Research Association, Chicago, IL. 21-25 April. http://eric. ed.gov/?id=ED478204

Moebius-Clune, B.N., I.H. Elsevier, B.A. Crawford, N.M. Trautmann, R.R. Schindelbeck, and H.M. van Es. 2011. Moving authentic soil research into high school classrooms: Student engagement and learning. J. Nat. Resour. Life Sci. Educ. 40:102-113. doi:10.4195/jnrlse.2010.0019k

Moskal, B.M., C. Skokan, L. Kosbar, A. Dean, C. Westland, H. Barker, Q. Nguyen, and J. Tafoya. 2007. K-12 outreach: Identifying the broader impacts of four outreach projects. J. Eng. Educ. 96:173-189. doi:10.1002/j.2168-9830.2007.tb00928.x

Montgomery, D.R. 2007. Soil erosion and agricultural sustainability. Proc. Natl. Acad. Sci. USA 104:13268-13272. doi:10.1073/ pnas.0611508104

Neo, M., and T.K. Neo. 2009. Engaging students in multimediamediated constructivist learning: Students' perceptions. Educ. Technol. Soc. 12:254-266.

National Science Teachers Association (NSTA). 2004. NSTA position statement: Scientific inquiry. http://www.nsta.org/about/positions/inquiry.aspx (accessed 10 Mar. 2016).

Next Generation Science Standards (NGSS). 2012. Development overview. Nextgenscience.org/development-overview (accessed 10 Dec. 2015).

Next Generation Science Standards (NGSS). 2013. Appendix A: Conceptual shifts in the Next Generation Science Standards. http://nextgenscience.org/sites/default/files/Appendix $\% 20$ A\%20-\%204.11.13\%20Conceptual\%20Shifts\%20in\%20 the $\% 20$ Next $\% 20$ Generation $\% 20$ Science $\% 20$ Standards.pdf (accessed 21 June 2016).

Page, M., M.S. Wilhelm, and N. Regens. 2011. Preparing graduate students for teaching: Expected and unexpected outcomes from participation in a GK-12 classroom fellowship. J. Coll. Sci. Teach. 40:32-37.
Stamp, N., and T. O’Brien. 2005. GK-12 partnership: A model to advance change in science education. Bioscience 55:70-77. doi:10.1641/0006-3568(2005)055[0070:GPAMTA]2.0.CO;2

Schusler, T.M., M.E. Krasny, S.J. Peters, and D.J. Decker. 2009. Developing citizens and communities through youth environmental action. Environ. Educ. Res. 15:111-127. doi: $10.1080 / 13504620802710581$

Steffen, W., K. Richardson, J. Rockström, S.E. Cornell, I. Fetzer, E.M. Bennett, R. Biggs, S.R. Carpenter, W. de Vries, C.A. de Wit, and C. Folke. 2015. Planetary boundaries: Guiding human development on a changing planet. Science 347:1-16. doi:10.1126/ science. 1259855

Strivelli, R.A., M. Krzic, C. Crowley, S. Dyanatkar, A.A. Bomke, S.W. Simard, and A. Jakoy. 2011. Integration of problem-based learning and web-based multimedia to enhance a soil management course. J. Nat. Resour. Life Sci. Educ. 40:215-223. doi:10.4195/jnrlse.2010.0032n

The White House. 2009. Remarks by the President at the National Academy of Sciences annual meeting. https://www.whitehouse. gov/the-press-office/remarks-president-national-academy-sciences-annual-meeting (accessed 14 Dec. 2015).

U.S. Environmental Protection Agency (USEPA). 2013. Mississippi River Gulf of Mexico Watershed Nutrient Task Force. Looking forward: The strategy of the federal members of the Hypoxia Task Force. https://www.epa.gov/sites/production/files/201503/documents/hypoxia_annual_federal_strategy_508.pdf (accessed 19 Dec. 2015). USEPA, Washington, DC.

United Nations Food and Agriculture Organization. 2015. International Year of Soils. http://fao.org/soils-2015/en/ (accessed 10 Dec. 2015).

White, P.T., K.J. Wolf, J.L. Johnson-Maynard, J.J. Velez, and S.D. Eigenbrode. 2014. Secondary climate change education in the Pacific Northwest. Nat. Sci. Edu. 43:85-93. doi:10.4195/ nse2014.01.0001

Wiest, S.L., L. Raymond, and R.A. Clawson. 2015. Framing, partisan predispositions, and public opinion on climate change. Glob. Environ. Change 31:187-198. doi:10.1016/j. gloenvcha.2014.12.006 